\title{
A tale of two rivers
}

\author{
Daniel R. Engstrom
}

Received: 1 November 2008/Accepted: 1 December 2008/Published online: 9 January 2009

(C) Springer Science+Business Media B.V. 2009

The Mississippi River is the largest and economically most important river in North America. It drains $40 \%$ of the conterminous United States, and like most of the world's major rivers, it has been substantially altered by centuries of wholesale land-use conversion, urbanization, and hydrological modification. Those changes are manifest in seriously impaired water quality along many of its reaches and an everwidening zone of bottom-water hypoxia in the northern Gulf of Mexico, where it discharges to the ocean (Rabalais et al. 2002).

At the other end of the Mississippi drainage system, some 850 river-kilometers from its headwaters in northern Minnesota, lies the confluence of two contrasting tributaries that in many ways epitomize the changes that the Mississippi has undergone (Fig. 1). One is the main-stem of the Mississippi itself, an often turbid and nutrient-rich waterway draining nearly half of the state of Minnesota $\left(100,000 \mathrm{~km}^{2}\right)$ including the large urban centers of Minneapolis and St. Paul, as well as $28,000 \mathrm{~km}^{2}$ of

This editorial is the introduction to a series of eight papers dedicated to the "Recent Environmental History of the Upper Mississippi River" published in this special issue of the Journal of Paleolimnology. D.R. Engstrom served as guest editor of the special issue.

D. R. Engstrom ( $₫)$

St. Croix Watershed Research Station, Science Museum of Minnesota, Marine-on-St. Croix, MN 55047, USA e-mail: dre@smm.org row-crop agriculture in the southern half of the state. The other is the St. Croix River, a major tributary draining $22,000 \mathrm{~km}^{2}$ of eastern Minnesota and northwestern Wisconsin, renowned for its high water quality and biological diversity, and one of the eight original US waterways included under the 1968 National Wild and Scenic River Act. While the St. Croix is often cited as a pristine example of what the conjoining Mississippi and other north-temperate rivers may have looked like prior to Euro-American settlement, the truth is that water quality in both rivers is impaired, though the Mississippi clearly more so than the St. Croix. Both rivers suffer from an apparent excess of phosphorus and the Mississippi from high levels of suspended solids (turbidity).

Major efforts are now underway to identify the various sources of impairment and to create longterm plans for reducing nutrient and sediment loads to the rivers. Such plans are technically known in the US as TMDLs (Total Maximum Daily Load). While such reduction goals are based largely on eco-region water-quality standards (as well as achievability), they require at their core an understanding of natural (background) loads such as might have occurred prior to Euro-American settlement. For most major rivers, an assessment of background conditions would be based on some type of watershed-runoff model or comparison to so-called "reference" systems thought to be minimally altered by human activity (e.g. Smith et al. 2003)—with all the uncertainty associated with such approaches. However, by fortunate "accident" 
Fig. 1 The confluence of the upper Mississippi and St. Croix rivers at Prescott, Wisconsin. Photo courtesy of David Morrison, Minnesota Pollution Control Agency

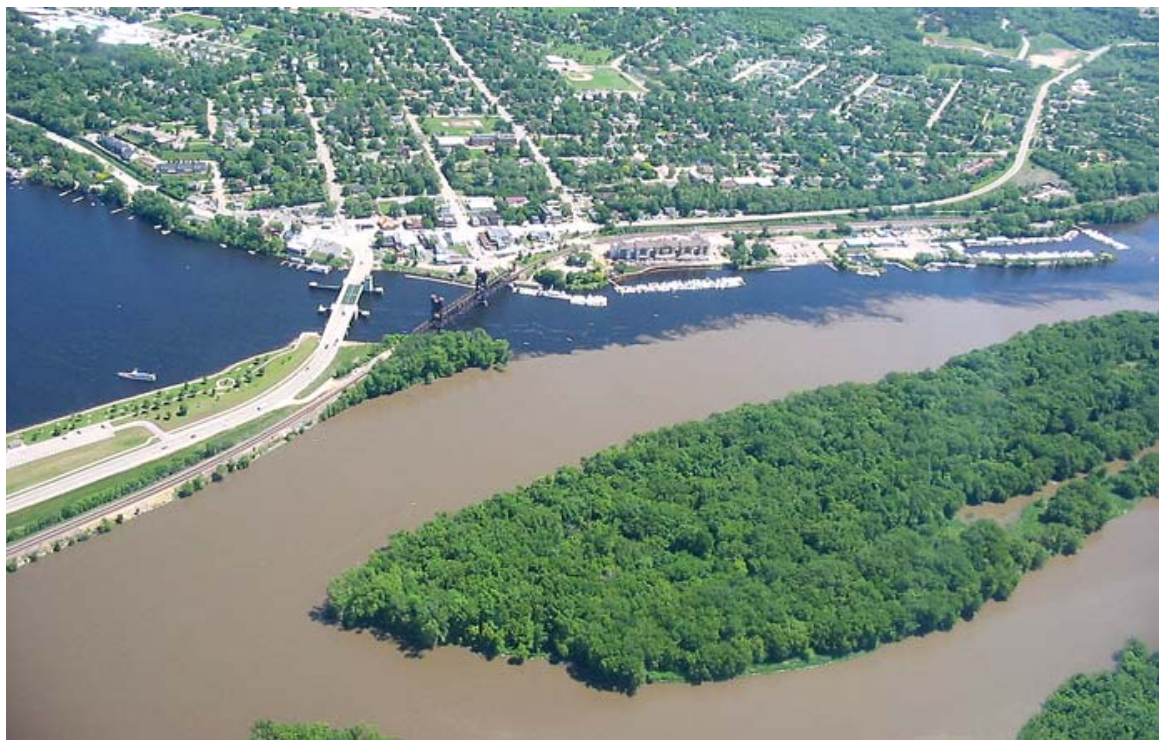

of geologic history, the St. Croix and upper Mississippi rivers possess along their courses natural riverine impoundments, which preserve in their sediments a historical record of changing land-use and water quality. This type of paleolimnological record can inform management efforts and the public at large on the natural state of these rivers, the magnitude of change, and by historical correlation the likely causes for that change.

This special issue of the Journal of Paleolimnology is devoted to a collection of interrelated studies that deal with the recent environmental history of the upper Mississippi River and its major tributary the St. Croix. The focus, in a paleolimnological sense, is on two natural, run-of-the-river impoundments, Lake Pepin and Lake St. Croix, located along the Minnesota-Wisconsin border. These lakes are geologically unusual, both by their mode of origin and by the fact that they allow us to use paleolimnological methods to examine long-term environmental change in large river systems-including the pre-settlement period so lacking in records from man-made reservoirs.

The major emphasis of the papers is on postEuropean impacts associated with agricultural conversion, urbanization, and industrial development during the last two centuries. The context for these changes is presented in the introductory paper by Blumentritt, Wright, and Stefanova, which summarizes the glacial-fluvial origin of the lakes and their post-glacial history. The remaining papers pick up the story near the onset of Euro-American settlement in the early 19th century and utilize multiple cores and mass-balance calculations to quantitatively reconstruct historical loading, outflow losses, and sedimentation. The challenges of multiple-core dating and correlation in riverine lakes are laid out in the papers by Engstrom, Almendinger, and Wolin, for Lake Pepin and by Triplett, Engstrom, and Edlund, for Lake St. Croix. These studies rely on diatominference models for reconstructing water-column phosphorus and outflow losses, the results of which are described in a separate paper for Lake St. Croix by Edlund et al. (a). Whole-basin sedimentation rates also provide the basis for a quantitative reconstruction of heavy-metal loading to the Mississippi River, as presented in the companion paper by Balogh and coauthors.

There is also a relatively long history-three decades-of water-quality monitoring in the upper Mississippi River. In the paper by Moraska Lafrancois, Magdalene, and Johnson, these instrumental data are compared with sediment-core trends in both Lake Pepin and Lake St. Croix. In addition, two of the papers in this issue document the likely drivers of the major changes recorded in the lakes. Mulla and Sekely compare the Lake Pepin record with historical landuse data, production of agricultural commodities, and population trends in the upper Mississippi basin, while Edlund et al. (b) quantify point-source phosphorus loads to the St. Croix River from the operational 
histories of waste-treatment facilities and demographic changes in the watershed.

Most of the studies presented in this issue were driven by the need to understand environmental change for the purposes of management and restoration. In that sense they have already had a large influence on policy development and the adoption of water-quality objectives for the two rivers. On the scientific side, the studies represent a major advancement in the application of paleolimnological methods to large river systems, especially in deriving quantitative reconstructions of sediment, nutrient, and contaminant loads through multiple-core, wholebasin analyses. And because of their close proximity and contrasting environmental histories, the upper Mississippi and St. Croix rivers constitute a largescale, paired-watershed experiment on the limnological consequences of land-use change. This special issue is thus a tale of two rivers told through the sediment records of two remarkable riverine lakes.

\section{References}

Balogh SJ, Engstrom DR, Almendinger JE, McDermott C, Hu J, Nollet YH, Meyer ML, Johnson DK (this issue) A sediment record of trace metal loadings in the upper Mississippi River. J Paleolimnol. doi:10.1007/s10933008-9295-2

Blumentritt DJ, Wright HE Jr, Stefanova V (this issue) Formation and early history of lakes Pepin and St. Croix of the Upper Mississippi River. J Paleolimnol. doi:10.1007/ s10933-008-9291-6

Edlund MB, Engstrom DR, Triplett LD, Moraska Lafrancois B, Leavitt PR (a) (this issue) Twentieth century eutrophication of the St. Croix River (Minnesota-Wisconsin, USA) reconstructed from the sediments of its natural impoundment. J Paleolimnol. doi:10.1007/s10933-008-9296-1

Edlund MB, Triplett LD, Tomasek MD, Bartilson K (b) (this issue) From paleo to policy: partitioning the historical point and nonpoint phosphorus loads to the St. Croix River, Minnesota-Wisconsin, USA. J Paleolimnol. doi: 10.1007/s10933-008-9288-1

Engstrom DR, Almendinger JE, Wolin JA (this issue) Historical changes in sediment and phosphorus loading to the upper Mississippi River: mass-balance reconstructions from the sediments of Lake Pepin. J Paleolimnol. doi: 10.1007/s10933-008-9292-5

Moraska Lafrancois B, Magdalene S, Johnson DK (this issue) Recent water quality trends and a comparison to sediment-core records for two riverine lakes of the upper Mississippi River basin: Lake St. Croix and Lake Pepin. J Paleolimnol. doi:10.1007/s10933-008-9294-3

Mulla DJ, Sekely AC (this issue) Historical trends affecting the accumulation of sediment and phosphorus in Lake Pepin, upper Mississippi River, USA. J Paleolimnol. doi:10.1007/ s10933-008-9293-4

Rabalais NN, Turner RE, Wiseman WJ Jr (2002) Gulf of Mexico hypoxia, AKA “The Dead Zone”. Annu Rev Ecol Syst 33:235-263. doi:10.1146/annurev.ecolsys.33.010802. 150513

Smith RA, Alexander RB, Schwarz GE (2003) Natural background concentrations of nutrients in streams and rivers of the conterminous United States. Environ Sci Technol 37:3039-3047. doi:10.1021/es020663b

Triplett LD, Engstrom DR, Edlund MB (this issue) A wholebasin stratigraphic record of sediment and phosphorus loading to the St. Croix River, USA. J Paleolimnol. doi: 10.1007/s10933-008-9290-7 